\title{
日本産蚊の国内分布に関する全国調査
}

\author{
前川芳秀* 津田良夫 沢辺京子 \\ 国立感染症研究所昆虫医科学部（162-8640 東京都新宿区戸山1-23-1）
}

（受領：2015年9月10日；登載決定：2015年11月7日）

\section{A nationwide survey on distribution of mosquitoes in Japan}

\author{
Yoshihide MaekawA*, Yoshio Tsuda and Kyoko Sawabe \\ *Corresponding author: maekawa@niid.go.jp \\ Department of Medical Entomology, National Institute of Infectious disease, \\ 1-23-1 Toyama, Shinjuku-ku, Tokyo 162-8640, Japan
}

(Received: 10 September 2015; Accepted: 7 November 2015)

\begin{abstract}
A nationwide survey of mosquito distribution in Japan was carried out in 2013 and 2014, in order to determine the current distribution of vector mosquitoes. Forty-two study sites located either in coastal or inland areas were selected from Hokkaido to Kyushu, and mosquitos were collected using CDC-like traps with $1 \mathrm{~kg}$ of dry ice (dry ice traps), a sweeping net and a dipper for collecting larvae. Ten dry ice traps were operated at each study site for 3 or 4 days. Larvae were collected from various bodies of water and carried to the laboratory, where they were reared until adult for species identification. The locations of the trap and larval collection sites were recorded using GPS. A total of 16,608 mosquitoes of 44 species and 11 genera were collected in this study. Adult density ranged between 0.002 and 16.51 adults/trap night among the 34 species collected by the dry ice traps. The geographical and altitudinal distributions of the mosquito species were compared. Culex tritaeniorhynchus, Cx. pipiens group, Aedes albopictus, and $C x$. orientalis were distributed widely and with a relatively high density of $>2$ adults/trap night, suggesting that these species are of high medical importance. In Hokkaido Ae. excrucians, Culiseta nipponica, and Ae. punctor/communis were collected at relatively high densities ranging between 0.51 and 1.98 adults/trap night, and are thus considered a locally abundant species.
\end{abstract}

Key words: mosquito, geographical distribution, dry ice trap, Japan

\section{緒言}

日本産蚊の国内の分布に関する研究は, LaCasse and Yamaguti（1950）によってまとめられ, その後医学的に重要 な種類を対象とした詳細な分布調査が上村（1968）によって 行われた. これらの研究では, 琉球列島と小笠原諸島は調査 の対象からはずされていたが，島嶼地域も含めた日本産蚊の 分類学と国内分布に関するもっとも包括的な研究が, Tanaka et al.（1979）によって行われている. さらに, 琉球列島産の 蚊に関しては 1975 年以降精力的な現地調查が行われ，2種の 新種と 4 種の新記録種を含めたモノグラフが Toma and Miyagi （1986）によって発表されている．2000年以降に行われた我 国産蚊の野外調査は特定の地域を対象にしたものであり（小 曾根ら, 2004, 2005; Higa et al., 2006; 津田ら, 2006a; Tsuda et al., 2009a, b; 白石, 2011; 山内, 2010), 全国的な調査は実施 されていない.

Tanaka et al.（1979）が日本産蚊の国内分布の研究を発表 してから約 40 年が経過し, その間に都市化による水田の消 失や沿岸部の干拓あるいは護岸に伴う湿地の消失, さらに は地球温暖化による気温の上昇などさまざまな環境変化が 起きている．これらの環境変化が, 蚊の生息密度あるいは 生息域に変化をもたらしていることは, 最近行われたいく つかの研究によって示されている。たとえば, ヒトスジシ
マカAedes albopictus (Skuse) の分布限界の北進（Kobayashi et al., 2002; 佐藤ら, 2012）や南方種の二セシロハシイエカ Culex vishnui Thobaldの琉球列島への侵入 · 定着 (Miyagi et al., 1992), 2011年3月に起きた東日本大震災の津波被災地で 報告されたアカイエカ群 $C x$. pipiens gr. やイナトミシオカ $C x$. inatomii Kamimura and Wadaの大発生（Tsuda et al., 2012; Tsuda and Kim, 2013; 津田ら, 2013; 渡辺ら，2012）などがその例 である。

蚊の医学的な重要性を考えれば, 疾病媒介蚊の国内分布は 可能な限り新しくかつ正確なことが望ましく, 分布に関する 情報を定期的に更新することが大切である. そこで, 本研究 は, 日本産蚊の国内分布の現状を明らかにすることを主目的 として，2013年，2014年に現地調査を行った。

本研究が目的としている国内分布調査のように, 広い地域 を対象として蚊の分布域を明らかにするためには, 蚊の生息 を確認し全国各地の多数の場所で調査を行う必要がある. そ の際, 調查場所の数が多ければ多いほど詳細な分布情報が得 られる一方で, 多地点で調査するためには莫大な労力と時間 が必要になる。 また, 遠隔地のように調査機会が限られる地 域では, 数回の調查によって生息しているすべての種類を明 らかにするのは非常に難しい. これらの問題を解決するひと つの手法として, ある種類の生息が確認された複数の地域に ついて生態的な情報を収集・分析し, その種類が生息する生 
態的条件に関する数学的モデルを作成して未調査地域におけ る生息を予測する研究が行われている（Franklin, 2009)。こ のような手法によって種の分布の予測地図を得るために使わ れる数学的モデルは “Species niche model” あるいは “Ecological niche model” と呼ばれ, サウジアラビアにおけるコガタアカ イエカ Cx. tritaeniorhynchus Gilesの分布や東南アジアやアフリ 力, 韓国におけるマラリア媒介蚊の分布の予測に利用されて いる (Levine et al., 2004; Foley et al., 2008, 2009; Obsomer et al., 2012; Sallam et al., 2013; Drake and Beier, 2014).

種の分布の予測地図の精度を高くするためには，生態的条 件が異なる多数の調査地を対象にして生息の有無を確認する 必要がある. そこで本研究は生息の有無に加えて, 将来的に 予測地図を作成する際の分析に有用な生態情報を収集できる ように, 気候や植生, 地形の違いに着目して調査地を選定し た. 本論文では，2013年と 2014年に行った日本産蚊の国内 分布調査結果を報告する。

\section{材料と方法}

\section{調査期間ならびに調査地}

2013年の調査は6月から 10 月まで北海道, 青森県, 秋田 県, 東京都, 静岡県, 愛知県, 岡山県, 広島県, 香川県, 愛 媛県，宮崎県の 1 都 1 道 9 県で原則として各 1 回（概ね 5 日 間）行った。2014年は 4 月から9月まで北海道，福島県，岐 阜県, 和歌山県, 山口県, 長崎県, 熊本県, 鹿児島県の 1 道 7 県で原則として各 1 回（概ね 5 日間）行った. 北海道の調 査は北方系ヤブカ類とハマダラカ類の発生時期が異なるた め, 2013年6月，2014年6,7月の 3 回行った。また岐阜県高 根と東京都奥多摩，長崎県対馬，鹿児島県出水ならびに鹳牟 田では幼虫採集のみ行った。調査地の合計は 42 力所で, 北 海道から九州まで東西南北に広範囲に位置しており，これに よって気候や植生の異なる地域を調査できるよう考慮した。 また地形の違いを考慮して, 調査地には沿岸部の水田地带と 内陸部の水田・丘陵地が含まれるように選んだ。本研究で 沿岸部は, 標高 $50 \mathrm{~m}$, 海岸からの距離 $5 \mathrm{~km}$ 以内とし, 標高 と距離から沿岸部と内陸部を区別した。ささらに $5 \mathrm{~km}$ を超え ても標高 $30 \mathrm{~m}$ 以下の低地は, 海岸から大規模な平野が広が る地域と考えられるため, 標高 $30 \mathrm{~m}$ 以下の調査地は距離に 関わらず沿岸部とした。各採集地点は, GPS（GARMIN 62S, WGS64）で緯度経度と標高を記録し，座標による調査地の 分布をFig. 1に示した. 海岸に近い発生源では標高がマイナ ス表示されることがあり，このような場合は，採集地の緯 度経度と地理院地図電子国土Web（国土地理院：http://maps. gsi.go.jp/）を用いて修正した. 各調查地の地理的位置は, ド ライアイストラップを設置した10力所の緯度・経度の平均 值を求め, それらの中心地点の座標で示した（Table 1). 各 調査地の海岸からの距離を示すために, 中心地点から最も近 い海岸線までの直線距離を地図上で求めた。さらに，各調査 地の標高は, ドライアイストラップ設置点 10 カ所の標高の 平均值で示した。

\section{採集および種同定法}

成虫採集は，津田ら（2006b）の方法に従い吸引式トラッ プと誘引源のドライアイス $1 \mathrm{~kg}$ を組み合わせたドライアイス トラップおよび捕虫網を用いて行った。 ドライアイストラッ プは調査地域内の湧水や小川, 池近くの茂み，水田や河川

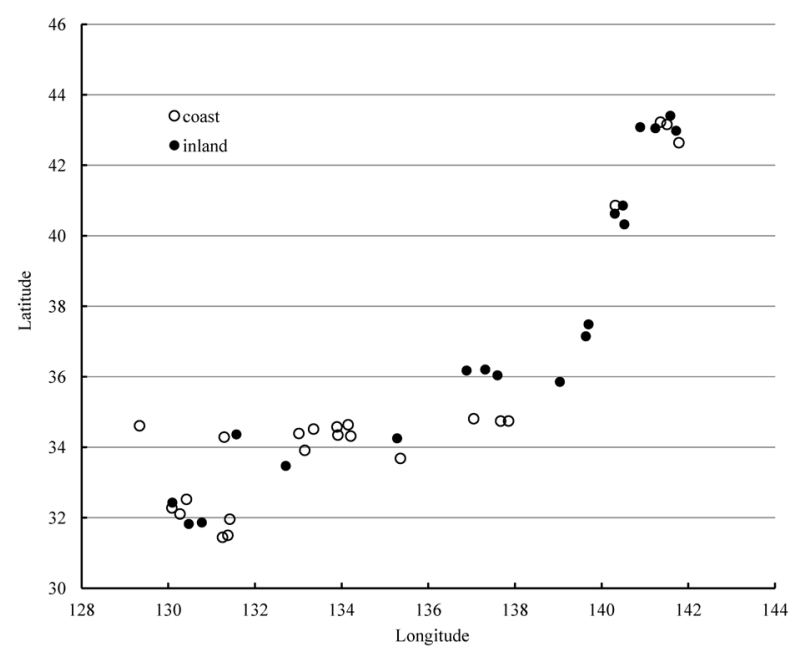

Fig. 1. Geographic locations of the 42 sites examined in this study.

敷, 公園, 寺社, 緑地, 岩礁や湿地, 防風林など周辺環境が 異なる10か所を選んで 1 台ずつ設置し，3晚もしくは 4 晚連 続して採集を行った。さらにドライアイストラップの設置場 所は風の影響を受けにくい場所を選び，樹木や柵などを利用 して地上から $1.5 \mathrm{~m}$ の高さに吊るし，15:00から翌朝 9:00ま で捕集した。 また捕虫網を用いてトラップ設置時や幼虫採集 時に調査者に誘引され飛来する成虫を捕集した．捕集した 成虫は, 生かした状態で宿舎へ持ち帰り, クロロホルムで 麻酔して種同定を行った．種同定はTanaka et al.（1979）の 検索表を用いて, 主に雌成虫の形態的特徵に基づいて行っ た. 雌成虫の形態では種同定が難しいとされる種類について はグループとして扱い，シナハマダラカ群Anopheles sinensis gr., クシヒゲカ亜属Culex (Culiciomyia) spp., アカイエカ群, チシマヤブカ/トカチヤブカAe. punctor/communisとして 示した. シナハマダラカ群にはシナハマダラカAn. sinensis Wiedemann, オオツルハマダラカAn. lesteri Baisas and $\mathrm{Hu}$, エ ンガルハマダラカAn. engarensis Kanda and Oguma, ヤツシロ ハマダラカAn. yatsushiroensis Miyazakiが含まれる. また, ク シヒゲカ亜属には, ヤマトクシヒゲカCX. sasai Kano, Nitahara and Awaya, キョウトクシヒゲカCX. kyotoensis Yamaguti and LaCasse, アカクシヒゲカCx. pallidothorax Thobald, クロフク シヒゲカCX. nigropunctatus Edwards, リュウキュウクシヒゲ カCX. ryukyensis Bohartが, さらにアカイエカ群には, アカイ エカCX. pipiens pallens Coquillett, ネッタイイエカCX.pipiens quinquefasciatus Say, 千カイ工力Cx. pipiens form molestus Forskalが含まれる. チシマヤブカ/トカチヤブカには, チ シマヤブカAe. punctor (Kirby) とトカチヤブカAe. communis (De Geer) が含まれる.

幼虫採集は柄杓や金魚網，ハンドポンプを用いて樹洞，小 川, 涌水, 古タイヤ, 沼, 湿地, 池, 河床水溜, 花筒, 手水 舎, 竹切株, 人工容器（ドラム午や空き午, ペットボトル, バケツなど)，コンクリートタンク，水田，側溝，栘，海岸 の岩礁や汽水域を対象として行った，採集した幼虫は，国立 感染症研究所昆虫医科学部（感染研）の実験室へ持帰り，工 ビオス粉末を与えて気温 $26.5 \pm 0.5^{\circ} \mathrm{C}$, 湿度 $57.6 \pm 0.9 \%$ の条件 で飼育し，羽化成虫を用いて種類を同定した． 
Table 1. Location, average altitude, and distance from the nearest seashore to the center of each study site examined in this study.

\begin{tabular}{|c|c|c|c|c|c|c|c|}
\hline No & Prefecture & Study site & Coast/inland & Latitude & Longitude & Altitude (m) & Distance (m) \\
\hline 1 & Hokkaido A & Aoyama & inland & 43.4059 & 141.5840 & 72.3 & 12401 \\
\hline 2 & Hokkaido B & Ishikari & coast & 43.2252 & 141.3564 & 5.8 & 2082 \\
\hline 3 & Hokkaido C & Toubetsu & coast & 43.1598 & 141.5067 & 6.9 & 16080 \\
\hline 4 & Hokkaido D & Ochiai & inland & 43.0823 & 140.8884 & 259.8 & 14103 \\
\hline 5 & Hokkaido E & Moiwa & inland & 43.0508 & 141.2389 & 184.6 & 13091 \\
\hline 6 & Hokkaido F & Naganuma & inland & 42.9802 & 141.7176 & 40.5 & 42668 \\
\hline 7 & Hokkaido G & Bentennuma & coast & 42.6412 & 141.7816 & 3.7 & 2718 \\
\hline 8 & Aomori A & Tsugaru & coast & 40.8588 & 140.3140 & 20.1 & 2644 \\
\hline 9 & Aomori B & Goshogawara & inland & 40.8570 & 140.4894 & 47.2 & 17526 \\
\hline 10 & Aomori C & Iwaki & inland & 40.6270 & 140.3023 & 374.8 & 19341 \\
\hline 11 & Akita & Oodate & inland & 40.3241 & 140.5232 & 130.5 & 42746 \\
\hline 12 & Fukushima A & Aizu & inland & 37.4871 & 139.6960 & 290.2 & 70680 \\
\hline 13 & Fukushima B & Minami aizu & inland & 37.1476 & 139.6343 & 843.4 & 94151 \\
\hline 14 & Gifu A & Furutaki & inland & 36.2045 & 137.3128 & 684.8 & 78715 \\
\hline 15 & Gifu B & Shirakawa & inland & 36.1759 & 136.8824 & 780.8 & 50351 \\
\hline $16^{*}$ & Gifu C & Takane & inland & 36.0402 & 137.5952 & 1270.3 & 83823 \\
\hline $17^{*}$ & Tokyo & Okutama & inland & 35.8550 & 139.0355 & 903.7 & 65783 \\
\hline 18 & Aichi & Nishio & coast & 34.8090 & 137.0465 & 28.7 & 3280 \\
\hline 19 & Shizuoka A & Iwata & coast & 34.7442 & 137.8517 & 23.8 & 9501 \\
\hline 20 & Shizuoka B & Hamamatsu & coast & 34.7419 & 137.6681 & 18.6 & 7887 \\
\hline 21 & Okayama A & Ushimado & coast & 34.6375 & 134.1493 & 21.8 & 2269 \\
\hline $22 *$ & Nagasaki & Tsushima & coast & 34.6089 & 129.3358 & 28.6 & 2166 \\
\hline 23 & Okayama B & Okayama & coast & 34.5766 & 133.8915 & 13.7 & 8742 \\
\hline 24 & Hiroshima A & Onomichi & coast & 34.5153 & 133.3513 & 23.7 & 10625 \\
\hline 25 & Hiroshima B & Mihara & coast & 34.3899 & 133.0129 & 28.8 & 6838 \\
\hline 26 & Yamaguchi A & Ikumo & inland & 34.3636 & 131.5713 & 245.7 & 16334 \\
\hline 27 & Kagawa A & Sakaide & coast & 34.3446 & 133.9128 & 21.1 & 2068 \\
\hline 28 & Kagawa B & Sanuki & coast & 34.3167 & 134.2096 & 50.8 & 3051 \\
\hline 29 & Yamaguchi B & Akiyoshi & inland & 34.2866 & 131.2893 & 154.8 & 10324 \\
\hline 30 & Wakayama A & Wakayama & coast & 34.2522 & 135.2797 & 14.1 & 13431 \\
\hline 31 & Ehime A & Saijou & coast & 33.9113 & 133.1488 & 13.3 & 1089 \\
\hline 32 & Wakayama B & Kiitanabe & coast & 33.6823 & 135.3558 & 17.4 & 0 \\
\hline 33 & Ehime B & Uchiko & inland & 33.4698 & 132.7096 & 285.4 & 23763 \\
\hline 34 & Kumamoto A & Kami amakusa & coast & 32.5216 & 130.4191 & 15.5 & 97 \\
\hline 35 & Kumamoto B & Shimo amakusa & inland & 32.4283 & 130.0926 & 92.8 & 6757 \\
\hline 36 & Kumamoto C & Ushibuka & coast & 32.2777 & 130.0822 & 23.7 & 1786 \\
\hline $37^{*}$ & Kagoshima A & Izumi & coast & 32.1056 & 130.2693 & 9.3 & 1149 \\
\hline 38 & Miyazaki A & Miyazaki & coast & 31.9579 & 131.4180 & 19.8 & 5547 \\
\hline 39 & Kagoshima B & Kirishima & inland & 31.8640 & 130.7736 & 455.0 & 16317 \\
\hline $40^{*}$ & Kagoshima C & Imuta & inland & 31.8223 & 130.4720 & 252.5 & 23487 \\
\hline 41 & Miyazaki B & Nichinan & coast & 31.5014 & 131.3741 & 24.9 & 485 \\
\hline 42 & Miyazaki C & Kushima & coast & 31.4438 & 131.2502 & 111.1 & 1945 \\
\hline
\end{tabular}

In each study site, 10 collection sites were selected for dry-ice trap collection. The average latitudes and longitudes of their positions were calculated and used as the center of the study site. *: Larval collection only.

\section{分布型の区分方法}

分布範囲の広狭と捕集密度の高低による分布型の区分を試 みた. 前者は成虫が捕集された調査地の数 (調査地数), 後 者はトラップ 1 台 1 日当たりの捕集個体数（捕集密度）を種 ごとに求めて評価した. 種ごとに求めた調査地数も捕集密度 も連続変数とみなすことができるが，值の大小関係によって 分布型を区分するための閾值を決める理論的な根拠は知られ ていない.しかしながら採集された調査地数の順に種を並べ れば，両極に位置する種，つまり多くの調査地で採集され広 域に分布すると思われる種（広域分布種）とわずか数か所の 調査地でしか採集されず分布が局所的と思われる種（局所分 布種）を区別することは可能である. 同様の操作は捕集密度
に関しても行うことができ，密度の高い順に種を並べて密度 が高い種（高密度種）と密度が低い種（低密度種）を区別す ることができる．また，広域分布種と局所分布種を区別する 調查地数の閾值を決めることは難しいので, 本研究では值 の上位と下位の 5 種を選んで広域分布種および局所分布種と し，残りの種はその中間に位置する種と考えた．捕集密度に 関しても同様に，密度の上位と下位の 5 種を選び，それぞれ 高密度種と低密度種, 残りの種は中間の密度とした. さらに このような区分を行った上で，分布の広さと密度の高さの 2 側面を考慮して調査結果を整理したところ，分布型として以 下の 4 つの型が区別された；広域・高密度種，広域・低密度 種, 局所 - 高密度種, 局所 - 低密度種. 本研究における具体 


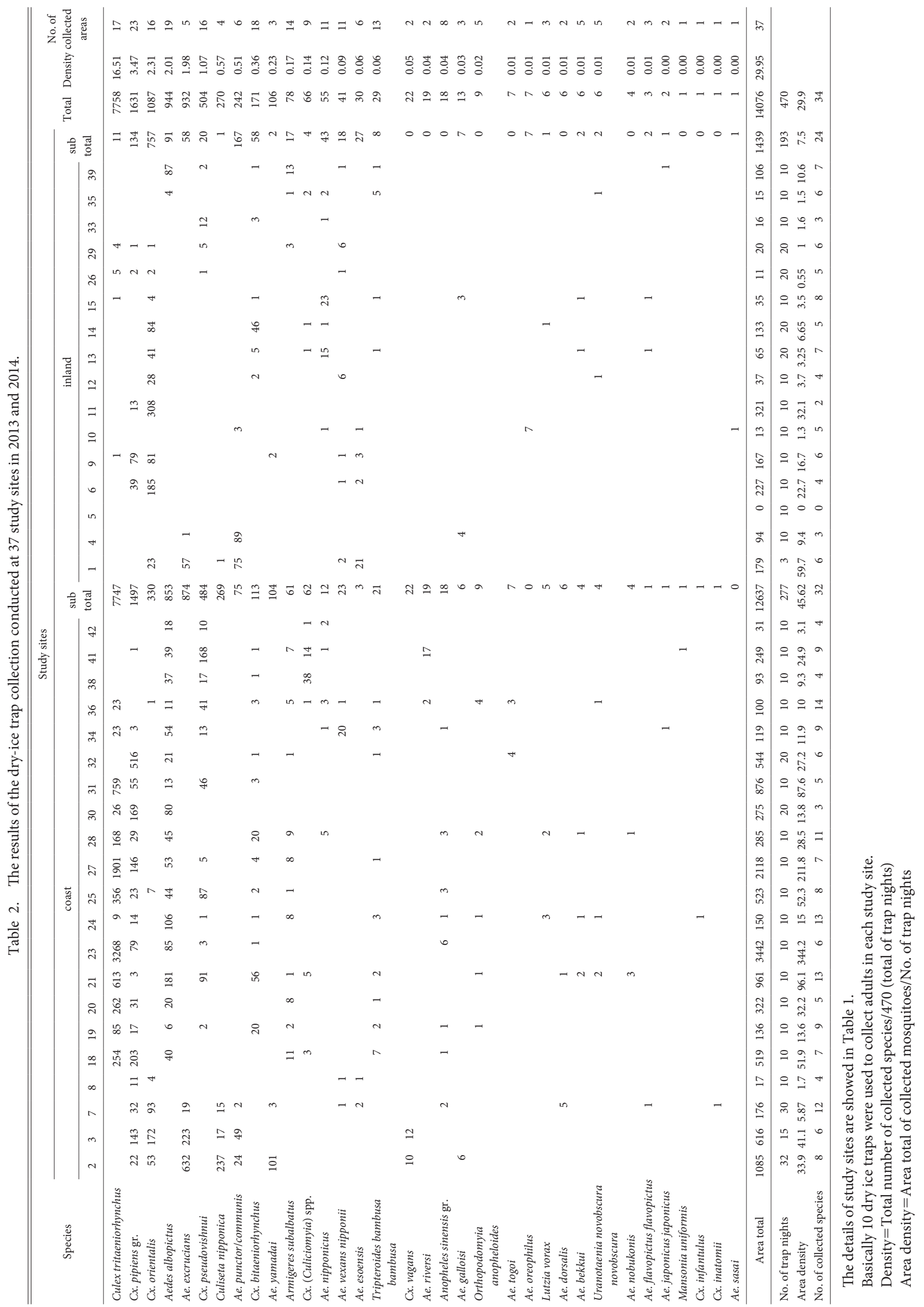


的な分布型の区分方法は，まず捕集密度の順位と分布の順位 ともに上位 5 位に入る種を選び，これらを広域・高密度種と した，逆に捕集密度の順位と分布の順位がともに下位 5 位に 入る種を選び，局所・低密度種とした。広域・高密度種の次 に捕集密度の順位が高い種のうち，分布の順位が低く，採集 された調査地数が明らかに少ない 3 種を局所・高密度種とし た．残った種の中で分布の順位が高く，捕集密度の順位が低 い種として 4 種を選び広域・低密度種とした。

\section{結果}

\section{成虫採集}

調査地の地理的分布と位置を Fig. 1 と Table 1 に示した. Fig. 1 で沿岸部の調査地は白丸（○), 内陸部の調査地は黒 丸（の）で示した。調査地の中で最も南に位置するのは宮 崎県串間（Table 1, 42 番，北緯 31.4438），最も北に位置する のは北海道東部の青山（Table 1, 1 番, 北緯 43.4059）であっ た. また, 最西端と最東端の調査地は, 長崎県対馬（Table 1,22 番, 東経 129.3358） と北海道東部の弁天沼（Table 1, 7 番, 東経 141.7816）であった. 調査地の平均標高は $3.7 \mathrm{~m}$ か ら 1,270.3 m, 海岸からの距離は $0 \mathrm{~m}$ から 94,151 m であった.

37 調查地（370採集地点，470 trap nights）で実施した ドライアイストラップ採集によって 10 属34種 14,076個体 (Table 2) が，また捕虫網採集では，17調査地で6属21種（ヤ ブカ一種, Aedes sp. を含む）379個体（Table 3）の成虫が捕
集された.

Table 2 にはドライアイストラップによる捕集個体数の多 い順に種類をリストして, 捕集総数を示した。 また，捕集 密度はDensity, 各採集地の捕集密度はArea densityとしてト ラップ 1 台 1 日当たりの捕集個体数を求めて表に示した. 得 られた結果から4つの分布型を区別し，それぞれの分布型 を示す種として 4 または 5 種を選んだ. 多数の調査地で捕 集され，トラップ1台1日当たりの捕集密度が高い種（広 域・高密度種）と考えられたのは, 以下の 4 種類であった； コガタアカイエカ 17 調查地 16.51 個体 / trap night, アカイ エカ群 23 調查地 3.47 個体 / trap night, ハマダライエカ $C x$. orientalis Edwards, 16調查地 2.31 個体 / trap night, ヒトスジ シマカ 19 調查地 2.01 個体 / trap night. これに対して, 多数 の調查地で捕集されたが捕集密度が低い種（広域・低密度 種）とされたのは, 以下の 5 種類であった; カラツイエカ Cx. bitaeniorhynchus Giles, 18 調査地 0.36 個体 / trap night, 才 オクロヤブカ Armigeres subalbatus (Coquillett), 14 調查地 0.17 個体 / trap night, キンパラナガハシカ Tripteroides bambusa bambusa (Yamada), 13 調査地 0.06 個体 / trap night, シロカ タヤブカAe. nipponicus LaCasse and Yamaguti, 11 調査地 0.12 個 体／trap night， キンイロヤブカAe. vexans nipponii (Thobald), 11 調査地 0.09 個体 / trap night. さらに捕集された調査地数 は少ないが捕集密度が高い種（局所・高密度種）としたの は, アカンヤブカAe. excrucians（Walker）５調査地1.98個

Table 3. The results of the sweep net collections conducted at 17 study sites in 2013 and 2014.

\begin{tabular}{|c|c|c|c|c|c|c|c|c|c|c|c|c|c|c|c|c|c|c|c|c|c|}
\hline \multirow{3}{*}{ Speices } & \multicolumn{19}{|c|}{ Study sites } & \multirow{3}{*}{ Total } & \multirow{3}{*}{$\begin{array}{c}\text { Collected } \\
\text { area }\end{array}$} \\
\hline & \multicolumn{8}{|c|}{ coast } & \multirow{2}{*}{$\begin{array}{l}\text { sub } \\
\text { total }\end{array}$} & \multicolumn{9}{|c|}{ inland } & \multirow{2}{*}{$\begin{array}{l}\text { sub } \\
\text { total }\end{array}$} & & \\
\hline & 2 & 3 & 7 & 8 & 22 & 32 & 36 & 41 & & 1 & 4 & 9 & 10 & 12 & 13 & 15 & 33 & 39 & & & \\
\hline Aedes excrucians & 37 & 58 & & & & & & & 95 & 82 & & & & & & & & & 82 & 177 & 3 \\
\hline Ae. punctor/communis & 1 & 4 & & & & & & & 5 & 39 & 6 & 1 & & & & & & & 46 & 51 & 5 \\
\hline Ae. albopictus & & & & & & 48 & & 1 & 49 & & & & & & & & & 1 & 1 & 50 & 3 \\
\hline Ae. flavopictus flavopictus & 1 & & & & & & & & 1 & & & 4 & & 7 & & 4 & 4 & 8 & 27 & 28 & 6 \\
\hline Ae. yamadai & 17 & 3 & & & & & & & 20 & & & & & & & & & & 0 & 20 & 2 \\
\hline Ae. esoensis & & & & 1 & & & & & 1 & & & 10 & 1 & & & & & & 11 & 12 & 3 \\
\hline Ae. nipponicus & & & & & & & & 3 & 3 & & & & 4 & & 1 & & & & 5 & 8 & 3 \\
\hline Ae. japonicus japonicus & & 1 & 2 & 2 & & & & & 5 & & & 1 & & & & & & & 1 & 6 & 4 \\
\hline Ae. riversi & & & & & & & & 6 & 6 & & & & & & & & & & 0 & 6 & 1 \\
\hline Ae. vexans nipponii & & & & & 3 & & 1 & & 4 & & & & & & & & & & 0 & 4 & 2 \\
\hline Armigeres (Armigeres) subalbatus & & & & & & 1 & & & 1 & & & & & 2 & 1 & & & & 3 & 4 & 3 \\
\hline Ae. sp. & & & 3 & & & & & & 3 & & & & & & & & & & 0 & 3 & 1 \\
\hline Culex pipiens gr. & & & & & & 1 & & & 1 & & & & 1 & & & & & & 1 & 2 & 2 \\
\hline Anopheles sineroides & & & & & 1 & & & & 1 & & & & & & & & & & 0 & 1 & 1 \\
\hline Cx. orientalis & & & & & & & & & 0 & & & 1 & & & & & & & 1 & 1 & 1 \\
\hline Ae. dorsalis & & & 1 & & & & & & 1 & & & & & & & & & & 0 & 1 & 1 \\
\hline Ae. oreophilus & & & & & & & & & 0 & & & & 1 & & & & & & 1 & 1 & 1 \\
\hline Ae. galloisi & & & & & & & & & 0 & & & & & & & 1 & & & 1 & 1 & 1 \\
\hline Ae. bekkui & & & 1 & & & & & & 1 & & & & & & & & & & 0 & 1 & 1 \\
\hline Ae. sasai & & & & 1 & & & & & 1 & & & & & & & & & & 0 & 1 & 1 \\
\hline Tripteroides bambusa bambusa & & & & & & & & & 0 & & & 1 & & & & & & & 1 & 1 & 1 \\
\hline Total & 56 & 66 & 7 & 4 & 4 & 50 & 1 & 10 & 198 & 121 & 6 & 18 & 7 & 9 & 2 & 5 & 4 & 9 & 181 & 379 & \\
\hline No. of days & 1 & 1 & 1 & 1 & 1 & 1 & 1 & 1 & & 1 & 1 & 1 & 1 & 1 & 1 & 1 & 1 & 1 & & & \\
\hline No. of collected species & 4 & 4 & 4 & 3 & 2 & 3 & 1 & 3 & & 2 & 1 & 6 & 4 & 2 & 2 & 2 & 1 & 2 & & & \\
\hline
\end{tabular}

The details of study sites are showed in Table 1 .

Mosquitoes attracted during larval collections and the setting of dry ice traps were collected by a sweep net. 
体 / trap night, ヤマトハボシカCuliseta nipponica LaCasse and Yamaguti, 4 調查地 0.57 個体 / trap night, チシマ/トカチ ヤブカ, 6 調查地 0.51 個体 / trap nightである. 最後に, 採 集された調査地が少なく捕集密度も低い種（局所・低密度 種）としたのは 4 種で, アシマダラヌマカMansonia uniformis (Theobald), フトシマツノフサカCX. infantulus Edwards, イ ナトミシオカ, ホッコクヤブカAe. sasai Tanaka, Mizusawa and Saugstadである. 本研究で広域・高密度種に区分された種 は, 37 調査地中 16 調查地以上で捕集され, 捕集密度が 2.0 個 体／trap nightより高い種であった。 広域・低密度種に区分 された種は, 11 以上の調査地で採集され捕集密度が 0.4 個体 ／trap nightよりも低い種であった. また, 局所・高密度種 は捕集された調査地の数が 6 以下と少ないが, 捕集密度が 0.5 個体／trap nightより高い種であり, 局所・低密度種は, 1 調查地のみで捕集され, 捕集密度が最も低い 0.002 個体 / trap nightを示す種であった。

沿岸部と内陸部の調査地を比較すると, ドライアイスト ラップで捕集された 34 種のうち 27 種は, 沿岸部での捕集密 度が内陸部より高かった. 捕集密度が高いコガタアカイエカ やアカイエカ群, ヒトスジシマカは低緯度の沿岸地域に集中 して分布し, ハマダライエカは内陸部で多かった. ハマダ ライエカは, 高緯度から低緯度まで幅広く分布しているが, 中・高緯度での捕集数が顕著に多かった. 北海道の沿岸部で は, ヤマトハボシカとアカエゾヤブカAe. esoensis Yamadaが, 内陸部の山中では, チシマヤブカ/トカチヤブカの捕集密度 が高かった. 採集地ごとの捕集種数を比較すると, 沿岸部 の調査地では 10 種以上の蚊が採集された調査地が 5 力所あつ た：種類数が多い順に熊本県牛深（36番）14種, 岡山県牛 空（21 番）と広島県尾道（24番）13種，北海道弁天沼（7番） 12 種, 香川県 (28 番) 11 種. 一方, 内陸部の調査地では 10 種類以上の蚊が採集された調査地はなく, 岐阜県白川（15 番）の 8 種が最も多く, 次いで福島県南会津（13番）と鹿児 島県霧島（39番）の7種であった.

トラップ設置時や幼虫採集を行っている際に吸血に来た成 虫の捕虫網採集の結果を Table 3 に示した. 合計6属21種の 蚊が採集されたが，そのうち16種はヤブカ属であった．特 にアカンヤブカとチシマヤブカ/トカチヤブカの襲来は著し く, 捕虫網を振る間隙を突いて吸血される程で, 他種とは比 較にならないほど激しかった。北海道で捕集したヤブカの一 種Aedes. sp. は, 頭頂部に狭横臥鱗片を有し後脚跗節基部に 白帯があり, 翅前部には鱗片がないためコガタキンイロヤブ カAe. bekkui Mogiに類似している. しかし, 口吻腹面に白色 部分はなく, 亜背版に鱗片がある点がコガタキンイロヤブカ とは明らかに異なっていた．主に北海道に分布し本州では稀 なミスジヤブカAe. galloisi Yamada が岐阜県白川（15番）の山 中で採集された。

\section{幼虫採集}

41 調查地で採集され感染研で室内飼育された幼虫からは, 10 属33種2,153個体の成虫が得られた（Table 4). 成虫採集 では捕獲されなかった種類は 8 種含まれ, そのうち 3 種は以 下のハマダラカ類だった; チョウセンハマダラカAn. koreicus Yamada and Watanabe, エセシナハマラダカAn. sineroides Yamada, ヤマトハマダラカAn. lindesayi japonicus Yamada. 北 方系のチシマヤブカ／トカチヤブカなどのセスジヤブカ亜
属Ae. (Ochlerotatus) sp. の幼虫は採集できなかったが, ト ワダオオカToxorhynchites towadensis (Matsumura), ハトリヤ ブカAe. hatorii Yamada, ワタセヤブカAe. watasei Yamada, コ ガタクロウスカ Cx. hayashii hayashii Yamada, ミナミハマダ ライエカCX. mimeticus Noé, エゾウスカCx. rubensis Sasa and Takahashiは, 成虫採集では捕集されていない種類である. 沿岸部と内陸部の調查地からはそれぞれ 27 種と 23 種の蚊種 が得られ, 両地域に共通する種は 17 種であった. 沿岸部で 多数採集されたのはヒトスジシマカとコガタアカイエカ, シナハマダラカ群で, これに対して内陸部で多く採集され たのはハマダライエカとヤマトヤブカAe. japonicus japonicus (Theobald), ヤマトハマダラカ, エセシナハマダラカであっ た. 調查地ごとに種類数を見ると, 比較的種類数が多く 10 種以上が採集されたのは, 内陸部の和歌山県和歌山（30番） 14 種, 次いで福島県南会津 (13番) 11 種, 沿岸部の熊本県 牛深 (36番) 11 種, そして長崎県対馬（22番）10種であった.

種類ごとに採集結果をみると, 41 調査地中最も多くの 調查地から採集された種は, ヤマトヤブカ19地点（438個 体）であった．次いでシナハマダラカ群，14調查地（193 個体)，13調査地から採集されたのはヒトスジシマカ（264 個体）とクシヒゲカ亜属（225個体），キンパラナガハシ カ (99個体), 12 調査地で採集されたのはコガタアカイエ カ（200個体）であった. Tanaka et al.（1979）によれば森 林に生息し比較的稀な種とされるトワダオオカの幼虫は青 森, 岐阜, 東京, 愛媛, 鹿児島の内陸部で採集された. 本 種の幼虫は, 落ち葉が沈んだ古タイヤおよび竹切株にお いて, キンパラナガハシカ, ヤマトヤブカ, ヤマダシマ カA A flavopictus Yamada, クシヒゲカ亜属, ハマダラナガ スネカ Orthopodomyia anopheloides (Giles), ブナノキヤブカ Ae. oreophilus (Edwards), フタクロホシチビカUranotaenia novobscura novobscura Barraudなどの幼虫と共に採集された. 九州地方では稀とされるワタセヤブカが熊本県天草の樹洞 からヒトスジシマカとリヴァースシマカA A riversi Bohart and Ingram幼虫と共に採集された。

幼虫が採集された 33 種について，幼虫の採集場所の標高 を Fig. 2に示した. 図では八マダラカ属を・, ヤブカ属をロ, イエカ属をム, それ以外の種類を×で示してある. 標高差に 対応した分布には属による違いは見られなかった. 約半数の 16 種は標高 $0 \sim 700 \mathrm{~m}$ の範囲の場所から採集された. 最も標 高の高い場所で採集された幼虫はヤマトハマダラカで, 標高 $1,374 \mathrm{~m}$ の河床の水草が生えている淀みから採集された. ヤ マトヤブカとクシヒゲカ亜属, キンパラナガハシカ, コガタ アカイエカ, ハマダライエカの幼虫は低地から $1,000 \mathrm{~m}$ を超 える山地まで広い範囲に位置する調査地で採集された. シマ カ亜属幼虫は, ヒトスジシマカとリヴァースシマカ, ワタセ ヤブカが標高 $200 \mathrm{~m}$ 以下の人工容器や樹洞などの発生源で採 集されたが, ヤマダシマカは低地から $1,000 \mathrm{~m}$ を超える山地 でも採集された．ブナノキヤブカ幼虫は，標高 $900 \mathrm{~m}$ 以上の 山地にある樹洞や落ち葉が沈んでいる古タイヤ, 縁石の穴な どから採集された. トワダオオカ幼虫はブナノキヤブカ幼虫 とは異なり, $100 \mathrm{~m}$ 程度の低地から $1,000 \mathrm{~m}$ 付近の山地の調査 地で採集されており, 生息に適した森があれば広く生息して いる事が示唆された. トウゴウヤブカAe. togoi (Theobald) や アカエゾヤブカ, ヤマトハボシカ, ワタセヤブカの幼虫は標 高 $20 \mathrm{~m}$ 以下の沿岸部からのみ採集され，これに対して内陸 


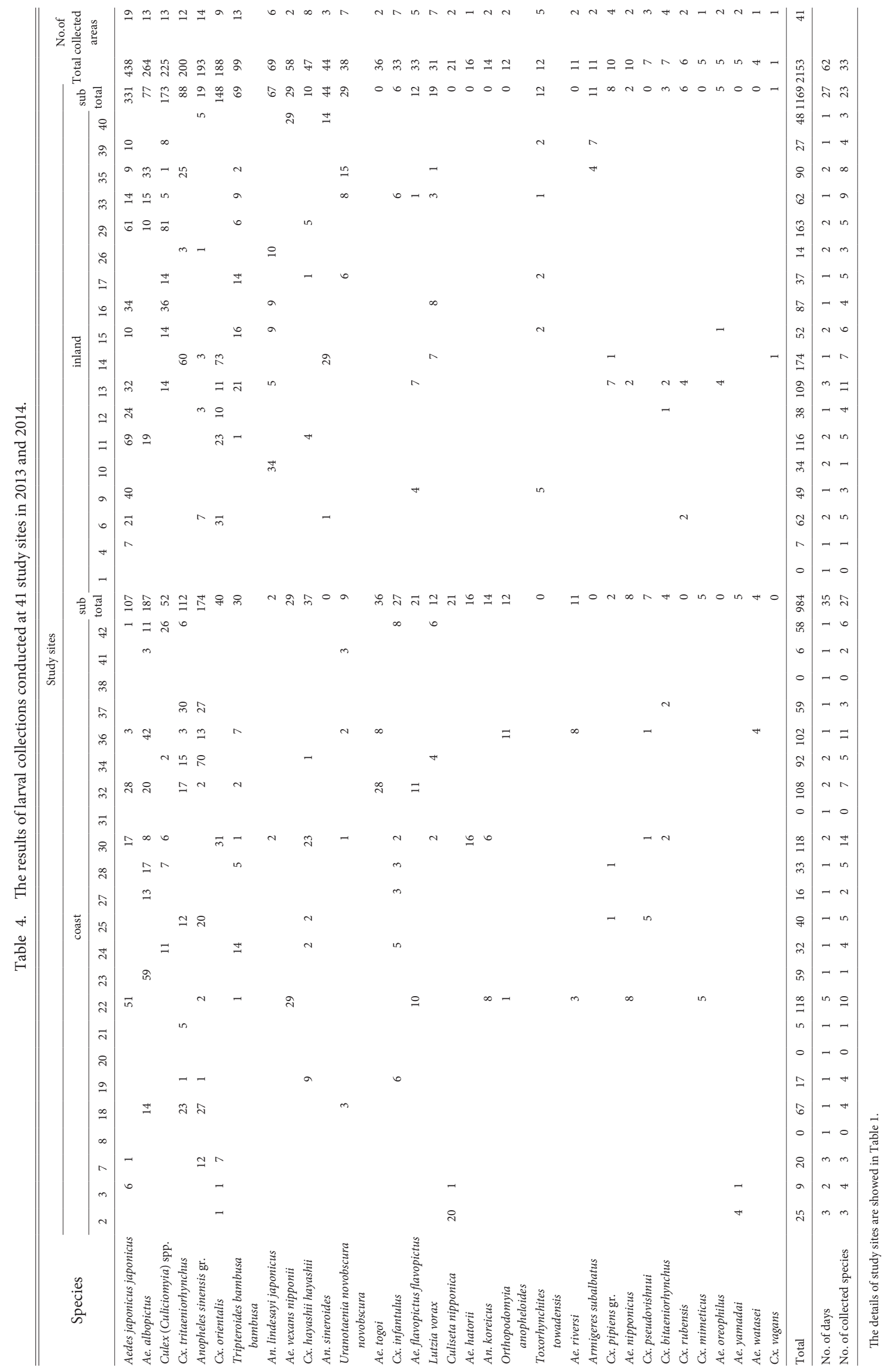




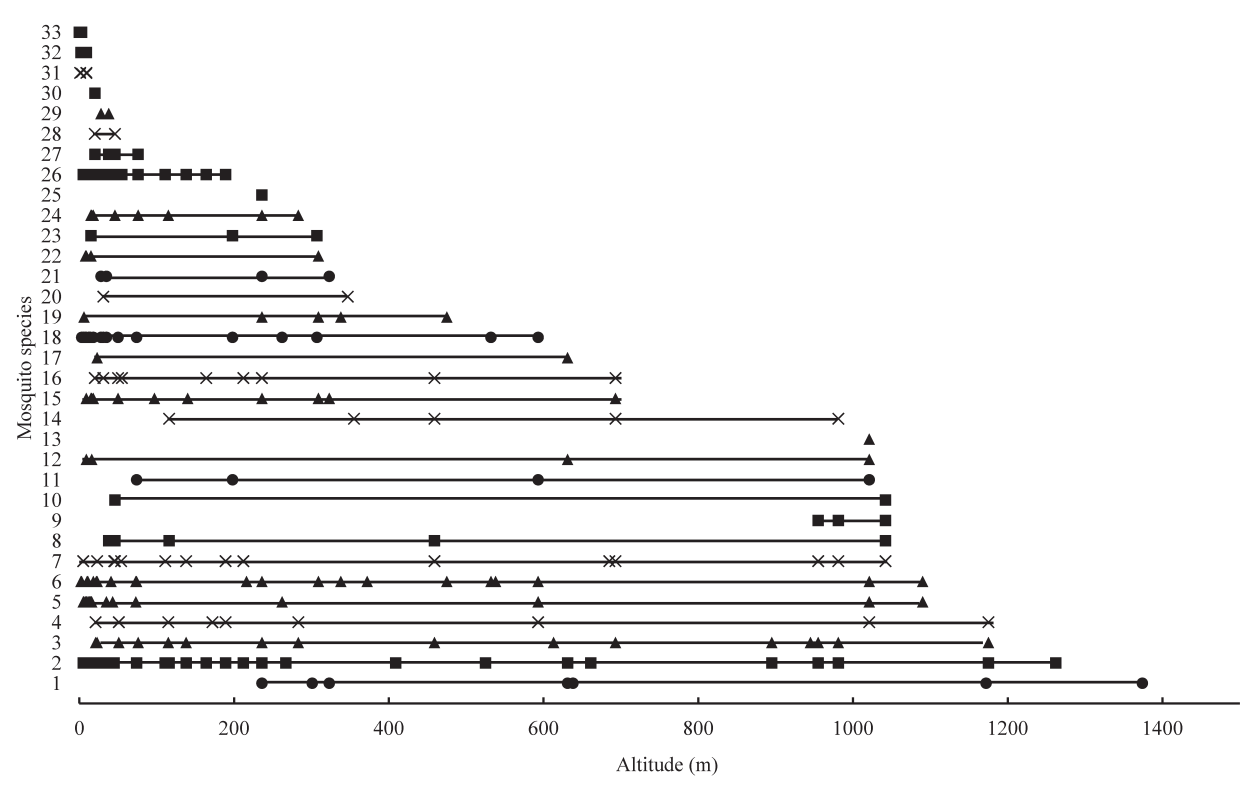

Fig. 2. Altitudes of the sites from which the larvae of 33 mosquito species were collected in this study.

$1=A n$. lindesayi japonicus, $2=A$ e. japonicus, $3=C x$. (Culiciomyia) spp., $4=L t$. vorax, $5=C x$. tritaeniorhynchus, $6=C x$. orientalis, $7=T p$. bambusa, $8=$ Ae. flavopictus, $9=$ Ae. oreophilus, $10=$ Ae. nipponicus, $11=A n$. sineroides, $12=C x$. pipiens gr., $13=C x$. vagans, $14=T x$. towadensis, $15=C x$. hayashii, $16=U r$. novobscura, $17=C x$. rubensis, $18=A$. sinensis gr., $19=C x$. bitaeniorhynchus, $20=A r$. subalbatus, $21=$ An. koreicus, $22=C x$. pseudovishnui, $23=$ Ae. vexans, $24=C x$. infantulus, $25=$ Ae. hatorii, $26=$ Ae. albopictus, $27=$ Ae. riversi, $28=$ Or. anopheloides, $29=C x$. mimeticus, $30=$ Ae. watasei, $31=$ Cs. nipponica, $32=$ Ae. yamadai, $33=$ Ae. togoi. $\boldsymbol{\bullet}=$ Genus Anopheles, $\mathbf{\square}=$ Genus Aedes, $\boldsymbol{\Delta}=$ Genus Culex, $\times=$ Genus Lutzia, Tripteroides, Toxorhynchites, Uranotaenia, Armigeres, Orthopodomyia, Culiseta.

部ではブナノキヤブカ幼虫が2調査地，スジアシイエカ $C x$. vagans Weideman とハトリヤブカの幼虫は 1 調査地でのみ採 集された.

\section{考察}

本研究で採集された蚊の種類と採集された調査地の数を, 3つの調査方法（ドライアイストラップ採集，幼虫採集，捕 虫網採集）ごとにまとめて Table 5 に示した．得られた種類 数はドライアイストラップ採集が最も多く 34 種, 次いで幼 虫採集で 33 種, 捕虫網採集は最も種類数が少なく 21 種だっ た. 成虫採集では捕集されず，幼虫採集でのみ採集された 種類は 8 種であった. 捕虫網採集で採集された種類は, 2 種 （エセシナハマダラカとヤブカの一種）を除いて，ドライア イストラップ採集でも捕集されていた．本研究の捕虫網採集 は，作業中に調査者に誘引され飛来した成虫を採集したもの であり，採集された蚊は人吸血性の種類である可能性が高 い. 蚊類の医学的重要度を考える際, 人吸血性は非常に重要 な性質であり，ある調查地の蚊相の調査方法としては人吸血 性の種類を効率よく採集できる方法が望ましい，このように 人吸血性の種類を採集することを重視して評価すると，本研 究で使用したドライアイストラップ採集法は捕虫網採集で捕 獲された人吸血性種のほとんどを捕獲しており, 適切な方法 であったということができるだろう。

ドライアイストラップ採集の利点について，津田（2013） は操作が簡便であること, 乾電池駆動であるため様々な場所 に設置できること, 夜行性の種類だけでなく昼行性の種類に も有効であること，吸血性でない昆虫類の採集数は少ないた めソーティング作業が容易であることなどをあげているが, これらの利点は本研究でも認められた。しかしながら, ト ラップを使用した捕集には久点もある。 もつとも致命的な欠 点は, トラップを適切な場所に設置しなければ周辺に生息し
ている蚊を捕集できないことである，本研究のドライアイス トラップ採集が適切に行われたかどうかを評価するために, 2001 年から 2011 年にかけて北海道から沖縄の 13 の調查地で ドライアイストラップを用いて行われた蚊相調査（津田, 2013）で捕集された種類を Table 5 に比較して示した. 津田 （2013）は 27 種を報告しているが，このうち 21 種が本研究の ドライアイストラップ採集でも捕集された. しかも，本研究 で多数の調査地で捕集された 10 種のうち9種は津田（2013） がリストした種と共通していることから, 本研究のドライア イストラップ採集は適切に実施されたと判断された。 Tanaka et al. (1979) が北海道から九州で採集した種類は69種であり, 本研究ではシナハマダラカ群やアカイエカ群, クシヒゲカ亜 属などは複数種を含むと考えられるため，69種のうち少な くとも 43 種（62\%）が採集されたことになる．また，Tanaka et al.（1979）で稀な種と記述されているのは合計29種である が, このうち 10 種 $(30 \%)$ が本研究で採集されている。本研 究では時間的制約のために, 各調查地での調查は原則として 1 回しか行われておらず，そのため調査地に生息している蚊 種のすべてを採集できたとは考えられないが，比較的生息密 度が高く, 人が遭遇する頻度が高い種類の多くが採集された と推測される.

過去に行われた広域にわたる蚊相調査, 例えば上村 (1968), Tanaka et al. (1979), Toma and Miyagi（1986）では, 幼虫調査が主体であったため, 成虫の生息密度に関する客観 的な評価はほとんど行われていない。生息密度や分布に関し ては普通 (common), 多い (abundant), 稀 (rarely collected) のような記述にとどまっている. しかしながら, 多数の地域 で多様な種を採集する中で, 種によって生息密度や分布域が 異なることに，多くの研究者が気付いていたことは間違いな いと思われる. 本研究で用いたドライアイストラップ採集法 は, トラップ1台 1 日当たりの捕集密度を求めることによっ 
Table 5. Comparisons of species occurrences observed in this study by three different methods, with data from previous studies.

\begin{tabular}{|c|c|c|c|c|c|}
\hline Species & Dryice Trap & Larval coll. & Sweep net ${ }^{1}$ & Tsuda $(2013)^{2}$ & Tanaka et al. $(1979)^{3}$ \\
\hline Culex pipiens gr. & 23 & 4 & 2 & $\bigcirc$ & \\
\hline Aedes albopictus & 19 & 13 & 3 & O & \\
\hline Cx. bitaeniorhynchus & 18 & 4 & & ○ & \\
\hline Cx. tritaeniorhynchus & 17 & 12 & & ○ & \\
\hline$C x$. orientalis & 16 & 9 & 1 & O & rare in Honshu \\
\hline Cx. pseudovishnui & 16 & 3 & & & \\
\hline Armigeres subalbatus & 14 & 2 & 3 & $\bigcirc$ & \\
\hline Tripteroides bambusa bambusa & 13 & 13 & 1 & $\bigcirc$ & \\
\hline Ae. nipponicus & 11 & 2 & 3 & $\bigcirc$ & \\
\hline Ae. vexans nipponii & 11 & 2 & 2 & $\bigcirc$ & \\
\hline Cx. (Culiciomyia) spp. & 9 & 13 & & ○ & \\
\hline Anopheles sinensis gr. & 8 & 14 & & O & \\
\hline Ae. punctor/communis & 6 & & 5 & & \\
\hline Ae. esoensis & 6 & & 3 & & \\
\hline Uranotaenia novobscura novobscura & 5 & 7 & & $\bigcirc$ & \\
\hline Orthopodomyia anopheloides & 5 & 2 & & O & \\
\hline Ae. excrucians & 5 & & 3 & & \\
\hline Ae. bekkui & 5 & & 1 & $\bigcirc$ & rare \\
\hline Culiseta nipponica & 4 & 2 & & & \\
\hline Lutzia vorax & 3 & 7 & & $\bigcirc$ & \\
\hline Ae. flavopictus flavopictus & 3 & 5 & 6 & $\bigcirc$ & \\
\hline Ae. yamadai & 3 & 2 & 2 & & rare \\
\hline Ae. galloisi & 3 & & 1 & & rare in Honshu \\
\hline Ae. japonicus japonicus & 2 & 19 & 4 & O & \\
\hline Ae. riversi & 2 & 2 & 1 & & rare in Kyushu \\
\hline Ae. togoi & 2 & 2 & & & \\
\hline Cx. vagans & 2 & 1 & & $\bigcirc$ & \\
\hline Ae. dorsalis & 2 & & 1 & & \\
\hline Ae. nobukonis & 2 & & & & rare \\
\hline Cx. infantulus & 1 & 7 & & $\bigcirc$ & rare in temperate Japan \\
\hline Ae. oreophilus & 1 & 2 & 1 & & \\
\hline Ae. sasai & 1 & & 1 & & \\
\hline Cx. inatomii & 1 & & & ○ & \\
\hline Mansonia uniformis & 1 & & & $\bigcirc$ & rare in temperate Japan \\
\hline Cx. hayashii hayashii & & 8 & & $\bigcirc$ & \\
\hline An. lindesayi japonicus & & 6 & & & \\
\hline Toxorhynchites towadensis & & 5 & & & \\
\hline An. sineroides & & 3 & 1 & $\bigcirc$ & \\
\hline An. koreicus & & 2 & & & \\
\hline Cx. rubensis & & 2 & & & rare in Honshu \\
\hline Ae. hatorii & & 1 & & & \\
\hline Ae. watasei & & 1 & & & rare in Kyushu \\
\hline Cx. mimeticus & & 1 & & & \\
\hline Ae. sp. & & & 1 & & \\
\hline No. of species & 34 & 33 & 21 & 23 & 10 \\
\hline
\end{tabular}

${ }^{1}$ Mosquitoes attracting to a collector were collected using a sweep net during the field survey.

${ }^{2}$ Species collected by the dry ice traps at 13 locations in Japan from 2001 to 2011 (Tsuda, 2013).

${ }^{3}$ Species described as "rare" species in Tanaka et al. (1979).

て，調査地における生息密度の多寡を定量的に示すことがで きた。そして生息が確認された調査地の数だけでなく，それ らの調査地における捕集密度を考慮することによって，分布 範囲の広さと生息密度を組み合わせた以下に示す 4 つの型を 区別することができた：広域・高密度種, 広域・低密度種, 局所・高密度種, 局所 - 低密度種. 蚊の生息に関して分布型 を区別することには次のような意義がある. 蚊の医学的重要 度は, 分布域の広さや捕集密度のような個体群生態学的特徴
に人吸血性を加味することによって，より適切に評価できる と思われる．広範囲にしかも高密度で生息する蚊は，媒介可 能な病原体が侵入した場合に集団としての疾病媒介力が大き いと考えられるので, 広域・高密度種は医学的に最重要な種 類と考えられる. 本研究で広域・高密度種と考えられたのは 4 種であるが, 人吸血性を加味するとこれら 4 種の中で医学 的重要度が高い種類は, コガタアカイエカ, アカイエカ群, ヒトスジシマカの 3 種ということができる. また, コガタア 
カイエカとアカイエカ群は標高 $1,000 \mathrm{~m}$ 付近でも幼虫が採集 されて抢り，垂直方向にも広く生息していた。 コガタアカイ エカは最も重要な日本脳炎ウイルス媒介蚊であり，アカイエ カ群は，アメリカではウエストナイルウイルスが検出されて いるが，我が国では同ウイルスは未検出のため潜在的媒介蚊 として知られている．さらに，ヒトスジシマカは 2014 年に 東京都の代々木公園とその周辺で起きたデングウイルスの流 行で最も重要な媒介蚊であった（Tsuda et al., 2015）.

本研究で局所・高密度種（採集された調査地の数は少ない が捕集密度が高い種）とされたのは，アカンヤブカ，ヤマト 八ボシカ, チシマヤブカ /トカチヤブカである.これらの中 でアカンヤブカとチシマヤブカ／トカチヤブカは, 雪融け の水溜りなどに幼虫が発生し（佐藤ら 1962, Dahl et al. 2004）, 昼夜を問わず激しく襲来して人を著しく吸血することが知 られているが，この吸血習性は本研究でも確認された。我 が国の場合，これらの種の分布は局所的であるが，生息密 度が高いことから医学的重要度は高いと言える。ブリテン 諸島では, チシマヤブカはウエストナイルウイルスのbridge vectorである可能性が示唆されており（Medlock et al. 2005）, 北欧や北米ではチシマヤブカやトカチヤブカのような雪融け 水の発生源から発生するヤブカ属は, Snowshoe Hare virus と Jamestown Canyon virusの重要な媒介蚊であるという報告も ある (Becker et al., 2010)。これら人畜共通感染症ウイルスの 侵入を監視し，国内外への拡散を抑制するためには，近縁種 を含めた北方系ヤブカ属の分布と生態, 生息密度を明らかに する必要がある.

過去の調査で稀種とされていた種類の中には，その後の調 査によってより広範囲に分布すると考えられるようになった 種類がある. 本研究で採集された種類の中では, コガタキン イロヤブカとイナトミシオカがその例と考えられる. 前者 は我が国の数力所のみで報告されている稀種とされていた が (Tanaka et al., 1979), 本研究では 5 調査地で採集された. 水田（2011）は大阪府の調査地で本種の発生を確認してい る。さらに，福島県の東日本大震災の津波被災地における調 査でも，捕獲個体数は少ないが，2力所でコガタキンイロヤ ブカが採集されていること（津田ら，2013）から，今後の調 査によってより正確な分布域が明らかにされるだろう。イナ トミシオカも岡山県の干拓地が唯一の生息地と思われていた が, その後の研究で大阪湾沿岸部, 東京湾沿岸部, 新潟県佐 潟湿地，釧路湿原などで生息が確認されている（Tsuda et al., 2009; Ejiri et al., 2011；水田ら，2012; Tsuda and Kim, 2013).さ らに本種は，東日本大震災の津波被災地でも大発生したこ とが報告されている（Tsuda et al., 2012；渡辺ら，2012; Tsuda and Kim, 2013)。 また，検疫所が港と空港を対象として実施 しているべクターサーベイランスでは，イナトミシオカは北 海道から本州にかけて広範囲に生息していることが示唆され ている (水田ら, 2012). 本研究では 1 調査地でしかイナト ミシオカは採集されていないが，これら既存の調査報告を考 慮すると，局所・低密度種とするよりは広域・低密度種に区 分する方が適切であるかもしれない.コガタキンイロヤブカ やイナトミシオカに限らず，これまでの調査では生息地が限 られるとされている種に関しては，今後の調査によって新た な生息地が見つかる可能性があり，それにともなって分布型 の区分も適宜検討する必要があるだろう。

本研究の幼虫採集と成虫採集の結果を比較すると, 同種で
あっても採集方法の違いにより採集される地域や数にばらつ きがあった。例えばヤマトヤブカは, ドライアイストラッ プでは 2 調查地から 2 個体, 捕虫網採集では 4 調查地から 6 個 体が採集されたが，幼虫採集でははるかに多く19調査地か ら438 個体の羽化成虫を得た. 主に内陸部の複数の発生源か ら採集され，この種が全国的に分布する普通種であることは 幼虫採集結果によって明らかである. 同様にハマダラカ亜属 も, ドライアイストラップ採集よりも幼虫採集での採集数が 多く, 内陸部の複数の調査地から採集された. さらに, トワ ダオオカ, トラフカクイカ Lutzia vorax Edwards, フトシマツ ノフサカ Cx. infantulus Edwards，クシヒゲカ亜属などの採集 方法は, ドライアイストラップより幼虫採集の方が適してい ると思われた. 一方, ヒトスジシマカやコガタアカイエカ, アカイエカ群は, ドライアイストラップ採集の方が幼虫採集 より採集数が多く, 各地での捕集成績が良かった. したがっ て，ある地域に生息する蚊の種類相をできるだけ正確に知る ためには, 本研究で実施したように, ドライアイストラップ による成虫採集と幼虫採集を組み合わせた調査を行うことが 現時点ではもっとも有効な方法であると思われる.

ドライアイストラップで捕集した蚊の捕集密度は，沿岸部 で 0.0036 27.97（個体／trap night），内陸部で 0.0052 3.92 （個体／trap night）であり，捕集した 34 種のうち25種は, 沿岸部での捕集密度が内陸部より高く, ヒトスジシマカやコ ガタアカイエカ, アカイエカ群は, 北緯 33 度から 35 度の沿 岸地域から高密度で捕集された。沿岸部は，低い丘陵地や平 地が広がり工業団地や市街地, 農耕地が多く, これらの地域 に存在する様々な環境（住宅地, 水田, 家畜舎, 水路, ため 池，公園，林など）は同時に，蚁の生息に適した多様な環境 を提供していると推測される. 本研究で示された, 沿岸部の ドライアイストラップでの捕集密度が内陸部よりも高い傾向 は, この推測を裏付けているように思われる.

日本脳炎媒介蚊であるコガタアカイエカは広域・高密度種 であり, 本研究で調査した $1,000 \mathrm{~m}$ 以上の山地でも幼虫が採 集されており, 人口密度の高い沿岸部を中心に日本各地に分 布している. 飼育豚での日本脳炎の流行は毎年繰り返されて おり, 日本脳炎ウイルス感染蚊も採集されていることから （佐藤ら, 2009；津田，2013；小林ら，2014）, 日本脳炎に感 染するリスクは依然として存在している. 本研究では, ウエ ストナイルウイルスの潜在的な媒介蚊として警戒されている アカイエカ群, ヒトスジシマカ, コガタアカイエカ, キンイ ロヤブカ, ヤマトヤブカ, ヤマダシマカ, シナハマダラカ （小林ら, 2003）が, 国内各地で採集された. ウエストナイ 儿熱ウイルス媒介蚊は, マラリアや日本脳炎などと比べると 多様であり, 生息場所や発生源, 季節消長, 吸血行動などが 異なるため, 重要な媒介蚁種は地域によって異なると予想さ れる. したがって, 地域ごとにどのような蚊が生息している かを正確に把握することが望まれる.

ある地域の蚁相を知るためには, 詳細かつ正確な調査が必 要であることは言うまでもないが，このような調査を実施す ることは実際にはかなり難しい。この問題は蚊に限ったこと ではなく, 多くの動植物でも同様の問題が存在している.あ る生物種の生息が確認された複数の地域について生態的な情 報を収集・分析し，その種の分布範囲を予測する手法は，現 在も様々な検討が進められており, 我が国においても分析に 必要な分布データの蓄積が何よりも重要である。これら情報 
は, 感染症対策の観点からも重要であり, その意味で本研究 のように広範囲にわたる多様な環境を対象にした蚊相調査を 可能なかぎり継続するべきである，今後は，蓄積されたデー タを基にした我が国の蚊の生息分布に対する Species niche modelの適用を行い, 蚊の予測分布地図の作成を試みたい.

\section{謝辞}

調査地の選定や幼虫サンプルの処理などに協力していただ いた星野啓太, 小川浩平両博士に感謝します. 本研究の一部 は厚生労働省科学研究費補助金（新型インフルエンザ等新 興・再興感染症研究事業（H24-新興-一般 007）ならびに国 立研究開発法人日本医療研究開発機構 (AMED) 新興・再興 感染症に対する革新的医薬品等開発推進研究事業および環境 省地球環境研究総合推進費（S-8）によって行われた.

\section{文献}

Becker, N., Petric, D., Zgomba, M., Boase, C., Madon, M., Dahl, C. and Kaiser, A. 2010. Mosquitoes and Their Control, 577 pp. Springer-Verlag Berlin Heidelberg, London.

Dahl, C., Nielsen, T. L. and Petersson, E. 2004. Mosquito larvae (Diptera: Culicidae) in snow-melt pools in a Swedish Lapland area. J. Vec. Ecol., 29: 109-123.

Drake, J. M. and Beier, J. C. 2014. Ecological niche and potential distribution of Anopheles arabiensis in Africa in 2050. Malar. J., 13: 213.

Ejiri, H., Sato, Y., Kim, K. S., Tsuda, Y., Murata, K., Saito, K., Watanabe, Y., Shimura, Y. and Yukawa, M. 2011. Blood-meal identification and prevalence of avian malaria parasite in mosquitoes collected at Kushiro Wetland, a subarctic zone of Japan. J. Med. Entomol., 49: 904-908.

Foley, D. H., Klein, T. A., Kim, H. C., Sames, W. J., Wilkerson, R. C. and Rueda, L. M. 2009. Geographic distribution and ecology of potential malaria vectors in the Republic of Korea. J. Med. Entomol., 46: 680-692.

Foley, D. H., Rueda, L. M., Peterson, A. T. and Wilkeron, R. C. 2008. Potential distribution of two species in the medically important Anopheles minimus complex (Diptera: Culicidae). J. Med. Entomol., 45: 852-860.

Franklin, J. 2009. Mapping species distributions, spatial inference and prediction. p. 320, Cambridge University Press, Cambridge, UK.

Higa, Y., Hoshino, K., Tsuda, Y. and Kobayashi, M. 2006. Dry icetrap and human bait collection of mosquitoes in the eastern part of Hokkaido, Japan. Med. Entomol. Zool., 57: 93-98.

上村 清. 1968. 日本における衛生上重要な蚊の分布と生 態. 衛生動物, 19: 15-34.

Kobayashi, M., Nihei, N. and Kurihara, T. 2002. Analysis of northern distribution of Aedes albopictus (Diptera: Culicidae) in Japan by geographical information system. J. Med. Entomol., 39: $4-11$.

小林睦生ら．2003．ウエストナイル熱媒介蚊対策に関する ガイドライン. 66 pp. 国立感染症研究所昆虫医科学部, 東 京.

小林大介, 伊澤晴彦, 江尻寛子, 佐々木年則, 前川芳秀, 吉 川亮，松本文昭，吾郷昌信，津田良夫，鍬田龍星，田 島 茂, 小林睦生, 太田伸生, 沢辺京子. 2014. 2012年押 よび2013年に長崎県で捕集されたコガタアカイエカCulex tritaeniorhynchusのアルボウイルス保有状況調查. 第49回 日本脳炎ウイルス生態学研究会抄録集, p. 52.

小曾根惠子，金山彰宏，神奈川県ペストコントロール協会. 2004. 横浜市における蚊成虫捕獲調査（2003年度）。ペス トロジー学会誌, 19: 103-108.

小曾根惠子，金山彰宏，神奈川県ペストコントロール協会.
2005。横浜市における蚊成虫捕獲調査—(第2 報) 一（2004 年度).ペストロジー, 20: 89-94.

La Casse, W. K. and Yamaguti, S. 1950. Mosquito fauna of Japan and Koreas, 268 p., App. I, The female terminalia of the Japanese mosquitoes, 7 p., App. II, Organization and function of malaria detachments, 213 p. Off. Surg., HQ. 8th Army APO 343 Japan.

Levine, R. S., Peterson, A. T. and Benedict, M. Q. 2004. Distribution of members of Anopheles quadrimaculatus Say s.l. (Diptera: Culicidae) and implications for their roles in malaria transmission in the United States. Am. J. Trop. Med. Hyg., 70: 105-109.

Medlock, J. M., Snow, K. R. and Leach, S. 2005. Potential transmission of West Nile virus in the British Isles: an ecological review of candidate mosquito bridge vectors. Med. Vet. Entomol., 19: 2-21.

Miyagi, I., Toma, T., Hasegawa, H., Tadano, M. and Fukunaga, T. 1992. Occurrence of Culex (Culex) vishnui Theobald in Ishigakijima, Ryukyu Archipelago, Japan. Jpn. J. Sanit. Zool., 43: 259-262.

水田英生. 2011. 大阪府の南部で採集された希少種コガタキ ンイロヤブカAedes bekkui とコガタフトオヤブカ Verrallina nobukonisの発生源と成虫および幼虫調查の結果. 衛生動 物, 62: 195-198.

水田英生, 上田泰史, 涌元美彰, 長谷山路夫, 森 英人, 白 石祥吾, 後藤郁夫. 2012. イナトミシオカCulex inatomii の分布について：検疫所の蚊族調查結果. 衛生動物, 63: 11-17.

Obsomer, V., Defourny, P. and Coosemans, M. 2012. Predicted distribution of major malaria vectors belonging to the Anopheles dirus complex in Asia: ecological niche and environmental influences. PLoS ONE, 7: e50475.

Sallam, M. F., Al Ahmed, A. M., Abdel-Dayem, M. S. and Abdullah, M. A. 2013. Ecological niche modeling and land cover risk areas for rift valley fever vector, Culex tritaeniorhynchus Giles in Jazan, Saudi Arabia. PLoS ONE, 6: e65786.

佐藤 卓, 松本文雄, 安部隆司, 二瓶直子, 小林睦生. 2012. 岩手県におけるヒトスジシマカの分布とGISを用い た生息条件の解析. 衛生動物, 63: 195-204.

佐藤正三, 富田 征. 1962. 阿寒及び知床の蚊. 北海道教育 大学紀要 (第二部), 13: 146-159.

白石祥吾. 2011. 愛媛県における蚊幼虫調査（2009年および 2010年の調査結果). 衛生動物, 62: 109-116.

佐藤 弘, 多屋馨子, 岡部信彦, 高崎智彦, 倉根一郎. 2009. わが国のブタにおける日本脳炎に対する抗体保有状 況 (感染症流行予測調査より). IASR, 30: 151-152.

Tanaka, K., Mizusawa, K. and Saugstad, E. S. 1979. A revision of the adult and larval mosquitoes of Japan (including the Ryukyu archipelago and the Ogasawara islands) and Korea (Diptera: Culicidae). Contrib. Am. Entomol. Inst., 16: 1-987.

田中和夫. 2005. 力科 Culicidae. 日本産水生昆虫, 科 - 属 種への検索 (川合禎次, 谷田一三編), pp. 757-1006, 東海 大学出版, 日本.

Toma, T. and Miyagi, I. 1986. The mosquito fauna of the Ryukyu archipelago with identification keys, pupal descriptions and notes on biology, medical importance and distribution. Mosq. Syst., 15: 1-109.

津田良夫. 2013. Science Watch, 蚁の観察と生態調査, 359 pp., 北隆館, 東京.

津田良夫, 比嘉由紀子, 葛西真治, 伊澤晴彦, 星野啓太, 林 利彦, 駒形 修, 澤邊京子, 佐々木年則, 冨田隆史, 二瓶 直子, 倉橋 弘, 小林睦生. 2006a. 成田国際空港近接地 と周辺地域の媒介蚊調査（2003, 2004年). 衛生動物, 57: 211-218.

津田良夫, 比嘉由紀子, 倉橋 弘, 林 利彦, 星野啓太, 駒 形 修, 伊澤晴彦, 葛西真治, 佐々木年則, 冨田隆史, 澤 邊京子, 二瓶直子, 小林睦生. 2006b. 都市域における疾 病媒介蚊の発生状況調査一ドライアイストラップを用いた 
2 年間の調査結果一. 衛生動物, 57: 75-82.

Tsuda, Y., Matsui, S., Saito, A., Akatani, K., Sato, Y., Takagi, M. and Murata, K. 2009a. Ecological study on avian malaria vectors on an oceanic island of Minami-Daito, Japan. J. Am. Mosq. Control Assoc., 25: 279-284.

Tsuda, Y., Sasaki, E., Sato, Y., Katano, R., Komagata, O., Isawa, H., Kasai, S. and Murata, K. 2009b. Results of mosquito collection from coastal areas of Tokyo Bay receiving migratory birds. Med. Entomol. Zool., 60: 119-124.

Tsuda, Y., Haseyama, M., Ishida, K., Niizuma, J., Kim, K. S., Yanagi, D., Watanabe, N. and Kobayashi, M. 2012. After-effects of Tsunami on distribution and abundance of mosquitoes in ricefield areas in Miyagi Prefecture, Japan in 2011. Med. Entomol. Zool., 63: 21-30.

津田良夫, 石田恵一, 山内 繁, 新妻 淳, 助廣那由, 梅澤 昌弘，柳 大樹，岡本徳子，沢辺京子． 2013. 東日本大震 災の津波が蚊の分布と発生数に与えた影響：宮城県南部水 田地帯と福島県沿岸部における2012年の調査結果. 衛生 動物，64: 175-181.

Tsuda, Y. and Kim, K. S. 2013. Outbreak of Culex (Barraudius) inatomii (Diptera: Culicidae) in disaster areas of the Great East Japan Earthquake and Tsunami in 2011, with ecological notes on their larval habitats, biting behavior and reproduction. J. Am. Mosq. Control Assoc., 29: 19-26.

Tsuda, Y., Maekawa, Y., Ogawa, K., Itokawa, K., Komagata, O., Sasaki, T., Isawa, H., Tomita, T. and Sawabe, K. 2015. Biting density and distribution of Aedes albopictus during the September 2014 outbreak of dengue fever in Yoyogi Park and the vicinity in Tokyo Metropolis, Japan. Jpn. J. Infect. Dis., 69: 1-5.

Wada, Y., Mogi, M., Oda, T., Mori, A., Suzuki, H., Hayashi, K. and Miyagi, I. 1976. Notes on Mosquitoes of Amami-Oshima Island and the overwintering of Japanese encephalitis virus. Trop. Med., 17: $187-199$

渡辺護, 渡辺はるな, 田原雄一郎, 平尾素一, Roychoudhury, S., 沢辺京子，石川善太，川端健人，菅野格 朗. 2012. 被害日本大震災の津波被害地における疾病媒介 蚊の発生状況. 衛生動物, 63: 31-43.

山内健生. 2010. 愛媛県宇和島市の有人島と本土で採集され た蚊類. 衛生動物, 61: 121-124. 